strongly support the notion ${ }^{6}$ that benzodiazepine, GABA and perhaps glycine receptors interact with the same chloride ion channels.

\section{DAVID RODBARD}

TOMMASO COSTA

Endocrinology and Reproduction

Research Branch,

National Institute of Child Health and Human Development

\section{CANDACE B. PERT}

Section on Biochemistry and Pharmacology,

Biological Psychiatry Branch,

National Institute of Mental Health, Bethesda, Maryland 20205

1. Costa. T., Rodbard, D. \& Pert. C. B. Nature 277, 315-317 (1979).

2. Tallman, J. F., Thomas, J. W. \& Gallager, D. W. Nature 274, 384-385 (1978)

3. Martin, I. L. \& Candy. J. M. Neuropharmacology 17, 993-998 (1978).

4. Kelly, J. S., Krnjevic. K., Morris. M. E. \& Yim, G. K. W. Expl Brain Res. 7. 14-31 (1969).

5. Eocles, J. C. in The Physiology of Synapses (ed. Eccles, J. C.) (Academic. New York, 1964)

6. Costa, T., Rodbard, D. \& Pert, C. B. in Physical Chemical A spects of Cell Surface Events in Cellular Regulation leds DeLisi, C. \& Blumenthal, R.) (Elsevier. Amsterdam, in the press).

7. Cabantchick, Z. 1. \& Tothstein, A. J. Membrane Biol. 15, 207-226 (1974).

\section{Another interpretation of communal breeding in green woodhoopoes}

LIGON AND LIGON' presented information which they stated "suggests helping is a strategy for personal gain", and concluded that their observations "do not support an interpretation of helping behaviour relying on kin-selected altruism." Obtaining critical evidence on these two points is difficult, perhaps justifying presentation of preliminary data. Nevertheless, it should be pointed out that their results are open to other interpretations and, in my view, they are entirely consistent with my proposed theory ${ }^{2}$ incorporating kin selection and individual selection, which they rejected.

Ligon and Ligon apparently invoked the personal-gain theory because the helpers showed no evidence of discrimination in their feeding of nestlings according to genetic relatedness. They did not actually demonstrate any personal gain; they merely inferred that it must exist because they saw that some helpers were not related to the young they fed. I consider this to be insufficient evidence on which to base the interpretation of personal gain. The few data presented are equally compatible with a zero-gain or even a loss (that is, altruism) hypothesis, as long as, on average, helping causes a gain in inclusive fitness to the helper. The apparent eagerness of helpers to feed young could be similarly explained.

Although personal gain to helpers by helping has been invoked by many authors and seems highly likely (for review see ref. $3)$, I know of no case in which a personal gain in terms of direct (individual) fitness has been convincingly demonstrated. Although there is some evidence for this ${ }^{4}$, firm empirical data based on a stronginference hypothesis are lacking. Apparently, Ligon and Ligon considered that their observations of a few helpers feeding unrelated young was inconsistent with kin-selection theory. They did not give their reasoning, but it seems to be based on two points: lack of discrimination of genetic relatedness in feeding efforts, and presence of presumed personal gain.

Discrimination was not evident in the few cases described, but the sample is unfortunately quite small (three cases). It may be of interest that a similar, though insignificant, lack of discrimination has been shown in jays (Fig. 1 of ref. 5). Even some parents in communal birds sometimes fail to discriminate between their own young and that of others (p. 375 of ref. 6), but one would not interpret this as evidence that parents in general have no genetic interest in their young. In any case, discrimination is not a necessary feature of kin selection ${ }^{7-12}$, even though some authors have written as if it were ${ }^{13}$.

Personal gain, although inconsistent with altruism, is entirely consistent with kin selection. This is not always evident in writings on kin selection ${ }^{13.14}$, but, as clearly shown by Hamilton ", the concept of inclusive fitness specifies that genetic costs and benefits be accounted across all relatives (not just offspring), regardless of the sign of the effect. My theory ${ }^{2}$ for the evolution of helping was based on a combination of kin selection and individual selection. Although I called helpers 'altruists', altruism or sacrifice by the helper was not a necessary or even desirable part of the theory, which is equally applicable when personal gain to the helper is involved.

As kin selection requires neither discrimination by relatedness nor individual sacrifice, it is difficult to see how the data of Ligon and Ligon are inconsistent with kin selection. The important condition is that the indirect fitness (inclusive fitness minus direct or individual fitness ${ }^{12}$ ) be raised by helping, and the Ligons did not consider this point.

\section{JERRAM L. BROWN}

Department of Biological Sciences, State University of New York, Albany, New York 12222

1. Ligon, J. D. \& Ligon, S. H. Nature 276, $496-498$ (1978).

2. Brown, J. L. Am. Zool. 14, 63-80 (1974)

3. Brown, J. L. A. Rev. ecol. Syst. 9, 123-155 (1978)

4. Woolfenden, G. E. \& Fitzpatrick, J. W. Bioscience 28, 104-108 (1978).

5. Brown, J. L. Anim. Behav. 20, 395-403 (1972).

6. Brown, J. Anim. Behat. 20, 395-403 (1972)

7. Maynard Smith, J. Nature 201, 1145-1147 (1964)

8. Maynard Smith, J. O. Ret. Biol. 51, 277-283 (1976)

9. Wilson, D. S. Prcc. nain. Acad. Sci. U.S.A. 72. 143-146 (1975).

10. Wilson, D. S. Am. Nat. 111, 157-185 (1977)

11. Hamilton W D J theor Biol 7, 1-52 (1964).

12. Brown, J. L. \& Brown, E. R. Sym. Natural Selection and Social Behavior. Univ. Michigan, Ann Arbor. (in the press)

13. Alexander. R. D. A. Rev. ecol. Syst. 5, 325-382 (1974)

14. Eberhard, M. J. W. Q. Ret. Biol. So, 1-33 (1975).
LIGON AND LIGON REPLY-Brown's major criticism of our report ${ }^{1}$ is that we rejected his theory ${ }^{2}$ incorporating both individual and kin selection in the evolution of avian helper systems. Actually, we questioned only kin-selected or phenotypic altruism ${ }^{3.4}$ in one kind of bird. Because green woodhoopoes can gain breeding status and helpers by first being helpers, whether or not they are related to the nestlings aided, we suggested that helping is a strategy for personal gain. For example, older birds gain and hold new breeding positions as a result of the support provided by younger individuals ${ }^{5}$. The system we describe corresponds to Hamilton's ${ }^{4}$ selected category and can also be referred to as cooperation ${ }^{6}$, reciprocal altruism ${ }^{7}$, reciprocity ${ }^{3}$ or mutualism $^{8}$. Kinship ties may or may not be present but are not required for this kind of behavioural interaction.

Brown proposes alternative explanations for our observations. We feel that because of the many unknown factors related to kin-selection theory ${ }^{9}$ the most parsimonious explanation for avian helping behaviour is personal or direct gain $^{10}$, when this can be ascertained. Very recently, Brown ${ }^{11}$ has acknowledged that kin selection may not always be involved in communal helper systems, and Brown and Brown 12 have urged abandonment of the term 'altruism' to refer to avian helping behaviour. Both points are addressed in our report and we support both suggestions.

\section{J. DAVID LIGON SANDRA H. LIGON}

\section{Department of Biology,}

The University of New Mexico, Albuquerque, New Mexico 87131

1. L.igon, J. D. \& L.igon, S. H. Nature 276, 496-498 (1978). 2. Brown. J. L. Am. Tonl. 14. 63-80 (1974).

3. Alexander, R. D. A. Rev. ecol. Syst. S, 325-382 (1974)

4. Hamileon, W. D. J. theor. Biol. 7, 1-52 (1964).

5 Ligon. $J$ D Symp. Natural Selection and Social Behavior. Univ. Michigan. Ann Arbor (in the press)

6. Emlen. S. T. in Behavioural Ecology: An Evolutionary Approach 245-281 (Sinauer. Sunderland. Massachusetts. 1978).

7. Trivers, R. L. O. Rev. Biol. 46, 35-57 (1971).

8. West Eberhard, M. J. Sciences 200, 441-443 (1978).

9. Flesness, N. R. Nature 276, 495-496 (1978).

10. Woolfenden, G. E. \& Fitzpatrick, J. W. Bioscience 28, $104-108$ (1978).

11. Brown. J. L. A. Rev. ecol. Syst. 9, 123-155 (1978).

12. Brown, J. L. \& Brown, E. R. Symp. Natural Selection and Social Behavior, Univ. Michigan, Ann Arbor (in the press).

\section{Subscriptions to Nature}

Personal subscriptions are available in the UK (£25) and USA/Canada (US\$52): payment must be made by personal cheque. Individual copies are available (post paid) at $£ 1$ in the UK and US\$3.50 (surface) or $\$ 5.00$ (air) in the rest of the world. Orders (with remittance) to:

Macmillan Journals Led, Brunel Road, Basingstoke, Hants RG21 2XS 